\title{
RANCANG BANGUN MONITORING ENERGI LISTRIK MENGGUNAKAN SMS BERBASIS MIKROKONTROLER ATMEGA328
}

\author{
Raden Ajeng Gusti Ramadhianti ${ }^{1}$, Ir. Cok Gede Indra Partha ${ }^{2}$, I Gusti Agung Pt \\ Raka Agung ${ }^{3}$ \\ Program Studi Teknik Elektro, Fakultas Teknik Universitas Udayana \\ Email : gstramaa@gmail.com ${ }^{1}$, cokindra@unud.ac.id ${ }^{2}$, puturaka@ee.unud.ac.id ${ }^{3}$
}

\begin{abstract}
ABSTRAK
Pelanggan PT. PLN (Persero) selama ini mendapatkan layanan program listrik prabayar dan pascabayar, pada listrik pascabayar PT. PLN masih menggunakan cara konvensial dalam memonitoring pemakaian energi listrik pelanggannya. Petugas PLN harus mencatat meter, menghitung dan menerbitkan rekening yang harus dibayar oleh pelanggan. Pada penelitian ini menggunakan sistem monitoring energi listrik menggunakan SMS yang dapat mengukur serta memantau pemakaian energi listrik secara real time, menggunakan metode pengukuran langsung. Hasil dari pembacaan sensor arus dan sensor tegangan akan diteruskan ke mikrokontroler untuk dikonversi menjadi jumlah konsumsi energi listrik dan jumlah pembayaran sesuai dengan tarif yang telah ditentukan PLN. Penelitian ini dilakukan di Laboratorium Dasar Teknik Elektro, Laboratorium Konversi Energi, Laboratorium Workshop \& Instalasi Listrik, Program Studi Teknik Elektro, Fakultas Teknik, Universitas Udayana.
\end{abstract}

Kata kunci : SMS, Energi Listrik, Monitoring

\section{ABSTRACT}

Customer PT. PLN (Persero) has been getting prepaid and postpaid electric service programs, on postpaid electricity PT. PLN is still using conventional ways to monitor the electricity consumption of its customers. PLN officers must record meters, calculate and publish accounts to be paid by customers. In this study using electrical energy monitoring system using SMS that can measure and monitor the use of electrical energy in real time, using the method of direct measurement. Results from the current sensor readings and voltage sensors will be forwarded to the microcontroller to be converted into the amount of electrical energy consumption and the amount of payment in accordance with tariffs that have been determined PLN. The research was conducted in Basic Laboratory of Electrical Engineering, Laboratory of Energy Conversion, Laboratory of Workshop \& Electrical Installation, Electrical Engineering Study Program, Faculty of Engineering, Udayana University.

Keywords: SMS, Electrical Energy, Monitoring

\subsection{PENDAHULUAN}

PT PLN (Persero) adalah perusahaan milik negara yang bergerak di bidang ketenagalistrikan baik dari mulai mengoperasikan pembangkit listrik sampai dengan melakukan transmisi kepada masyarakat di seluruh wilayah Indonesia [1].

Pelanggan PT. PLN (Persero) selama ini mendapatkan layanan program listrik prabayar dan pascabayar, namun pada program listrik pascabayar sering terjadi human error pada saat petugas melakukan pembacaan meter. Program listrik pascabayar merupakan program bagi pelanggan untuk menggunakan energi listrik terlebih dahulu kemudian membayar pada bulan berikutnya. Setiap bulannya PT. PLN (Persero) harus mencatat meter, menghitung dan menterbitkan rekening yang harus dibayar oleh pelanggan dengan memasang sebuah alat ukur bernama kilo Watt hours $(\mathrm{kWh})$ meter disetiap rumah pelanggan yang berfungsi sebagai mesin pencatat pemakaian energi listrik yang dilengkapi dengan pembatas besar daya maksimal yang digunakan. Saat ini masyarakat luas secara umum mengenal $\mathrm{kWh}$ meter konvensional yang memiliki banyak keterbatasan, kWh 
meter konvensional hanya melakukan pengukuran terhadap daya aktif dan data hasil pengukuran berupa data analog yang hanya dapat dibaca melalui tampilan pada $\mathrm{kWh}$ meter tersebut, sehingga selalu dibutuhkan operator manusia yang bertugas untuk melakukan pencatatan data dengan cara mendatangi lokasi dimana kWh meter tersebut dipasang.

Pada penelitian ini, dibangun suatu sistem monitoring energi listrik menggunakan SMS (Short Message Service) yang dapat mengukur serta memantau pemakaian energi listrik secara real time, menggunakan sensor tegangan serta sensor arus SCT013-030. Hasil pembacaan sensor dan tegangan akan diteruskan ke mikrokontroler untuk dilakukan konversi terhadap jumlah konsumsi energi listrik dan jumlah pembayaran sesuai dengan tarif yang telah ditentukan PLN.

\subsection{KAJIAN PUSTAKA}

\subsection{Daya}

Daya pada arus bolak-balik atau alternating current (AC) ada 3 macam yaitu daya aktif, daya reaktif dan daya nyata [2]. Segitiga daya dapat dilihat pada Gambar 1.

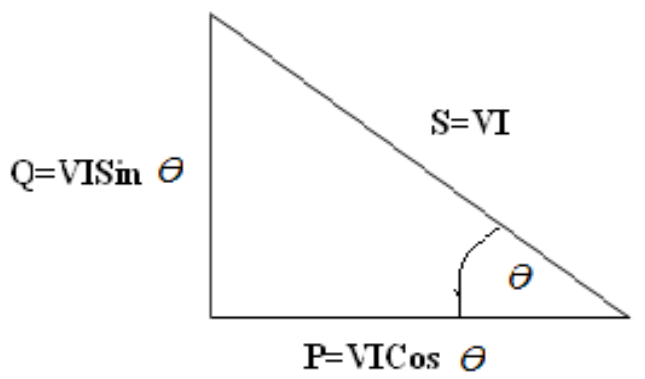

Gambar 1. Segitiga Daya

\section{Daya Aktif}

Daya aktif digunakan secara umum oleh konsumen. Daya aktif inilah yang biasanya dapat dikonversikan dalam bentuk kerja. Satuan daya aktif dinyatakan dalam watt. Daya aktif (real power), didapat dari persamaan berikut:

$$
P=V \cdot I \cdot \cos \theta[k W]
$$

\section{Daya Reaktif}

Daya reaktif adalah jumlah daya yang diperlukan untuk pembentukan medan magnet. Dari pembentukan medan magnet. Maka akan terbentuk fluks magnet. Satuan daya reaktif dinyatakan dalam VAr. Daya reaktif (reactive power), didapat dari persamaan berikut:

$$
Q=V \cdot I \cdot \sin \theta[k V A]
$$

3. Daya Nyata

Daya nyata adalah penjumlahan geometris dari daya aktif dan daya reaktif. Daya nyata merupakan daya yang diproduksi oleh perusahaan sumber listrik untuk diditribusikan ke konsumen. Satuan daya nyata ini dinyatakan dalam VA. Daya nyata (apparent power), didapat dari persamaan berikut:

$$
S=V . I[\mathrm{kVA}]
$$

Daya aktif dan reaktif didefinisikan secara matematika dengan menggunakan persamaan berikut:

$$
\sqrt{P^{2}+J Q^{2}}=S
$$

\section{$2.2 \mathrm{kWh}$ Meter Analog}

kWh meter merupakan alat ukur energi listrik yang mengukur secara langsung hasil kali tegangan dan arus. Pada penelitian ini $\mathrm{kWh}$ meter yang digunakan adalah kWh meter 1 phasa dengan layanan program listrik pascabayar. kWh meter analog ditunjukkan pada Gambar 1.

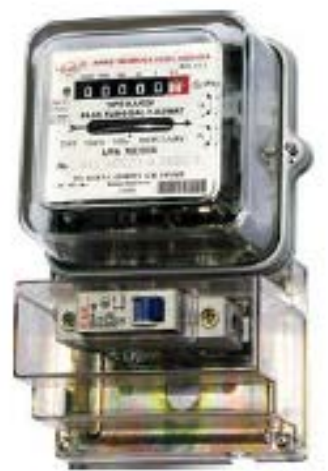

Gambar 2. kWh Meter Analog

1. Perhitungan pada kWh Meter Analog Implementasi alat monitoring energi listrik menggacu pada penetapan penyesuaian tarif tenaga listrik PLN bulan November 2016, dengan Golongan Tarif Rumah Tangga ( $R-1)$ dengan batas daya 1.300VA s.d 2.200VA, Rumah Tangga (R2) dengan batas daya 3.500VA s.d 5.500VA, Rumah Tangga (R-3) dengan batas daya 6.600VA ke atas, dengan ketentuan diterapkan Rekening Minimun (RM). Penetapan penyesuaian tarif tenaga listrik PLN bulan November untuk Rumah 
Tangga (R-1) s.d Rumah Tangga (R-3) ditunjukkan pada Gambar 3.

\begin{tabular}{|c|c|c|c|c|c|}
\hline No. & $\begin{array}{l}\text { Gol. } \\
\text { Tarif }\end{array}$ & $\begin{array}{l}\text { Batas } \\
\text { Daya } \\
\text { (VA) }\end{array}$ & $\begin{array}{c}\text { Biaya Beban } \\
\text { (RpplkVAlbulan) }\end{array}$ & $\begin{array}{c}\text { Biaya } \\
\text { Pemakaian } \\
\text { (RpplkWh) } \\
\text { dan Biaya } \\
\text { kVArh } \\
\text { (RpplkVArh) }\end{array}$ & $\begin{array}{l}\text { Pra Bayal } \\
\text { (RpplkWh) }\end{array}$ \\
\hline 1. & $\begin{array}{c}R \cdot \\
1 \pi R \\
\end{array}$ & $\begin{array}{c}1.300 \mathrm{~s} .0 \\
2.200\end{array}$ & \multirow{3}{*}{$\begin{array}{l}\text { RM1= } 40 \text { (Jam } \\
\text { Nyala) X Daya } \\
\text { Tersambung } \\
(\text { KVA) X Biaya } \\
\text { Pemakaian }\end{array}$} & $1.467,28$ & $1.467,28$ \\
\hline 2. & $\begin{array}{c}\text { R. } \\
2 \pi R\end{array}$ & $\begin{array}{c}3.500 \mathrm{~s} .0 \\
5.500\end{array}$ & & $1.467,28$ & $1.467,28$ \\
\hline 3. & $\begin{array}{c}R \cdot \\
3 \pi R\end{array}$ & $\begin{array}{l}6.600 \mathrm{ke} \\
\text { atas }\end{array}$ & & $1.467,28$ & $1.467,28$ \\
\hline
\end{tabular}

Gambar 3. Tarif Dasar PLN

\subsection{Mikrokontroler ATmega328}

Arduino adalah papan rangkaian elektronik (electronic board) open source yang didalamnya terdapat komponen utama yaitu, sebuah chip mikrokontroler. Mikrokontroler itu sendiri adalah suatu chip atau IC (Integrated Circuit) yang bisa diprogram menggunakan komputer [3]. Pada penelitian ini menggunakan mikrokontreler ATmega328. Mikrokontroler ATmega328 ditunjukkan pada Gambar 4.

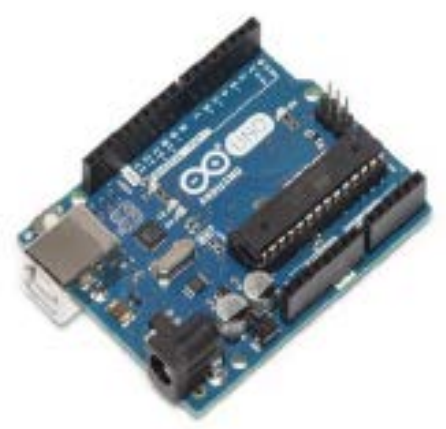

Gambar 4. Mikrokontroler ATmega328

\subsection{Sensor Tegangan}

Komponen tegangan adalah sensor tegangan yang berfungsi untuk menentukan tegangan jala-jala listrik, hal ini diperlukan untuk mengukur tegangan setiap saat. Sensor tegangan ini berupa pembagi tegangan. Tegangan yang dihasilkan masih berupa sinyal sinusoidal. Tegangan ini akan diteruskan ke input rangkaian penyearah [4]. Rangkaian pembagi tegangan ditunjukkan pada Gambar 5.

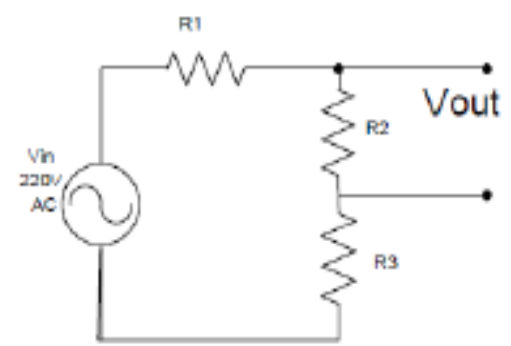

Gambar 5. Rangkaian Pembagi Tegangan

\subsection{Sensor Arus}

Sensor arus adalah alat yang digunakan untuk mengukur kuat arus listrik. Sensor arus pada penelitian ini menggunakan sensor arus SCT (Splilt-core Current Transformer) tipe SCT013-030.

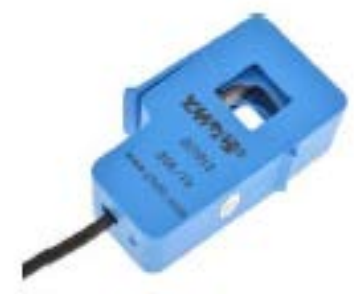

Gambar 6. SCT013-030

\subsection{Data Logger}

Data logger adalah suatu alat elektronik yang berfungsi mencatat data dari waktu ke waktu secara continue [5]. Pada perancangan terdapat sistem data logger yang dapat digunakan untuk merekam data yang diolah oleh mikrokontroler, terdapat module RTC dan module micro SD card. Module RTC akan menampilkan informasi mengenai keterangan waktu dan tanggal secara real time saat proses pembacaan sensor dan konversi berjalan, sedangkan module micro $S D$ card berfungsi sebagai media penyimpan data. Pada penelitian ini module micro SD card yang digunakan berkapasitas 2 GB.

\subsection{Buzzer}

Buzzer adalah suatu alat yang dapat mengubah sinyal listrik menjadi sinyal suara. Pada umumnya buzzer digunakan untuk alarm, karena penggunaannya cukup mudah yaitu dengan memberikan tegangan input maka buzzer akan mengeluarkan bunyi atau suara. Frekuensi suara yang dikeluarkan oleh buzzer yaitu antara 1-5 $\mathrm{kHz}$ [6]. Pada penelitian ini buzzer berfungsi sebagai alarm notifikasi pelanggan ketika pelanggan memasuki 
waktu pembayaran. Buzzer ditunjukkan pada Gambar 7.

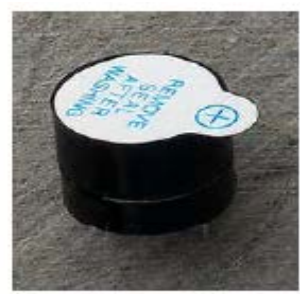

Gambar 7. Buzzer

2.8. Module GSM (Global Sistem for Mobile Communication)

SIM900A GSM GPRS Module merupakan module GSM/GPRS Serial Modem yang dikeluarkan oleh ITeadstudio. SIM900A GSM GPRS module digunakan untuk beberapa fitur, diantaranya fitur GPRS, telephone, serta mengirim dan menerima data menggunakan SMS (Short Message Service) berbasis ATmega328. SIM900A GSM GPRS Module ditunjukkan pada Gambar 8.

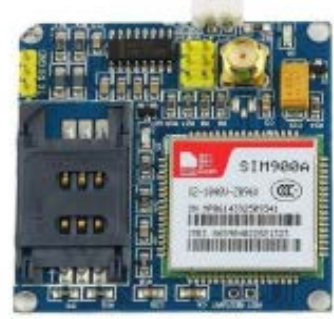

Gambar 8. SIM900A GSM GPRS Module

\section{METODOLOGI PENELITIAN}

Perancangan dalam penelitian ini dilakukan dalam beberapa tahapan, diantaranya :

1. Mengumpulkan study literature.

2. Membuat perancangan hardware, perancangan software, serta proses pengujian.

Rancang bangun monitoring energi listrik menggunakan SMS berbasis mikrokontroler ATmega328 menggunakan metode pengukuran langsung dengan sensor arus SCT013-030 serta sensor tegangan yang memanfaatkan sistem transformator pada perangkat modulenya, perancangan ini dibagi menjadi menjadi dua, yaitu perancangan perangkat keras (hardware) dan perancangan lunak (software), sebelum membuat perancangan hardware dan software dibutuhkan diagram alir sebagai acuan dalam proses pembuatan monitoring energi listrik menggunakan SMS berbasis mikrokontroler
ATmega328. Gambar 9 merupakan diagram alir dari proses perancangan dalam penelitian.
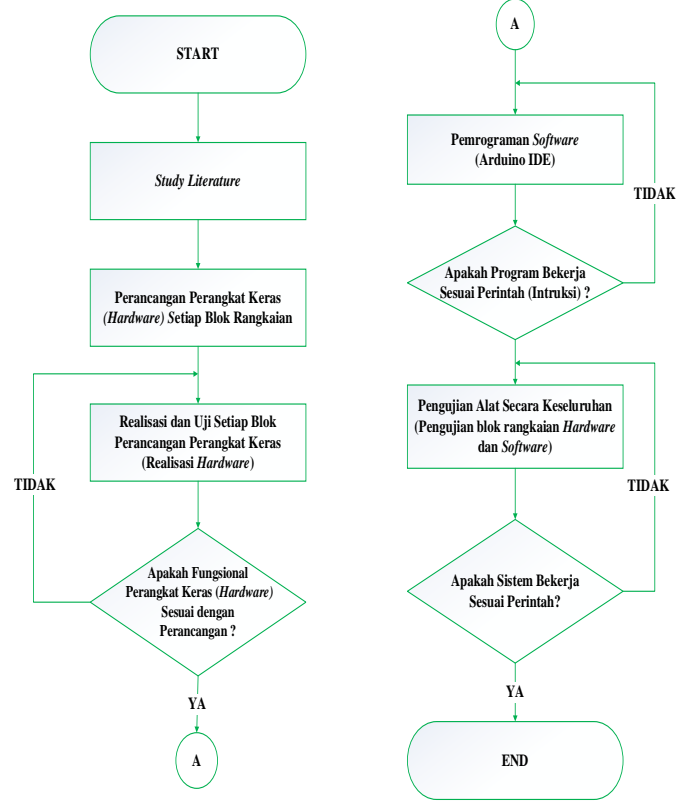

Gambar 9. Diagram Alir Dari Proses Perancangan Dalam Penelitian

\subsection{Perancangan Perangkat Keras (Hardware) \\ Pada implementasi sistem pemonitor} energi listrik menggunakan SMS berbasis mikrokontroler ATmega328, menggunakan sebuah software, yaitu software Diptrace 3.0.0.2 untuk pembuatan skematik dan layout PCB. Diagram blok sistem pemonitor energi listrik menggunakan SMS berbasis mikrokontroler ATmega328 ditunjukkan pada Gambar 10.

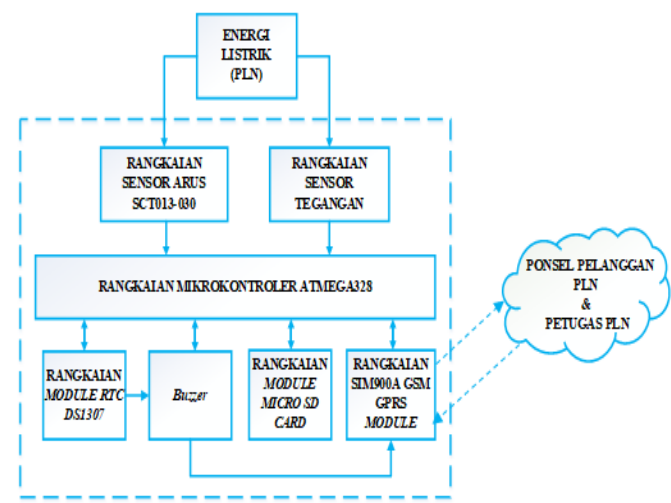

Gambar 10. Perancangan Perangkat Keras

Secara umum implementasi perancangan sistem monitoring energi listrik menggunakan SMS berbasis mikrokontroler ATmega328 ini, menggunakan sensor arus 
SCT013-030 dan sensor tegangan berbasis mikrokontroler ATmega328, dengan input dari energi listrik (PLN). Energi listrik (PLN) akan masuk melewati sensor arus SCT013030 dan melewati sensor tegangan, output dari sensor arus dan sensor tegangan adalah energi listrik, yang kemudian diteruskan ke mikrokontroler. Jumlah energi listrik yang masuk akan dikonversi menjadi jumlah pembayaran yang telah ditetapkan PLN. Hasil pembacaan dan konversi harga akan ditampilkan pada LCD.

Perancangan perangkat keras (hardware) terdiri dari:

1. Rangkaian mikrokontroler ATmega328.

2. Rangkaian sensor arus SCT013-030.

3. Rangkaian sensor tegangan.

4. Rangkaian LCD.

5. Rangkaian module Micro SD Card.

6. Rangkaian module Real Time Clock.

7. Rangkaian SIM900A GSM GPRS Module sebagai pengirim SMS.

8. Rangkaian module Buzzer.

\subsection{Perancangan Perangkat Lunak} (software)

Perancangan perangkat lunak terdiri dari diagram alir. Diagram alir (flowchart) merupakan gambaran proses kerja sistem monitoring energi listrik menggunakan SMS berbasis mikrokontroler ATmega328. Diagram alir (flowchart) program dari rancang bangun kWh meter sms monitoring berbasis mikrokontroler ATmega328 ditunjukkan pada Gambar 11a dan Gambar 11b.

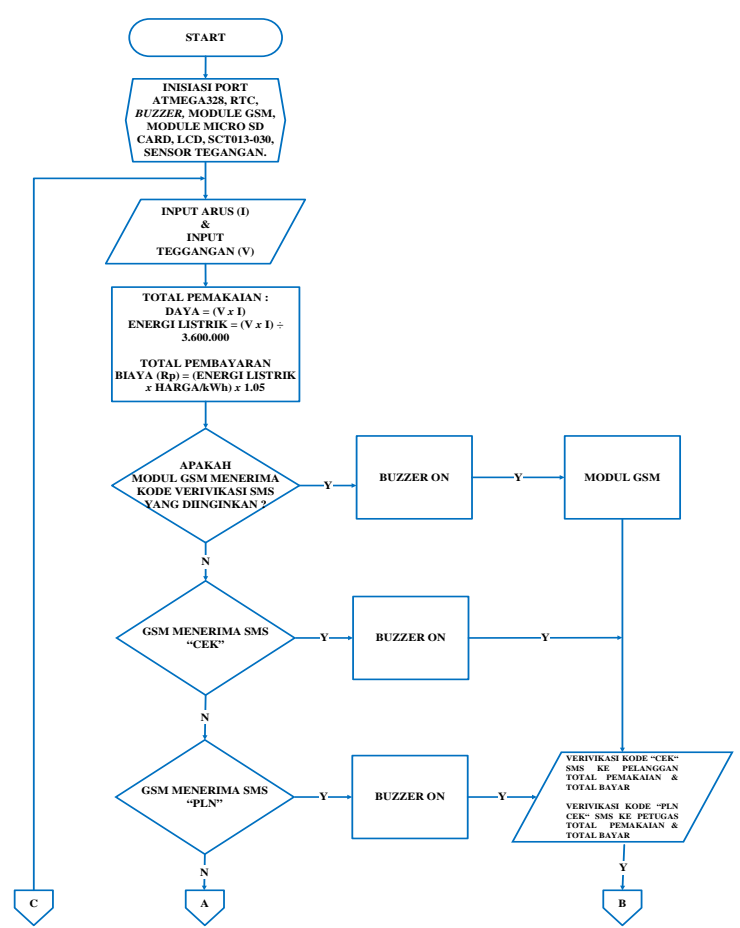

Gambar 11a. Diagram alir (flowchart) program

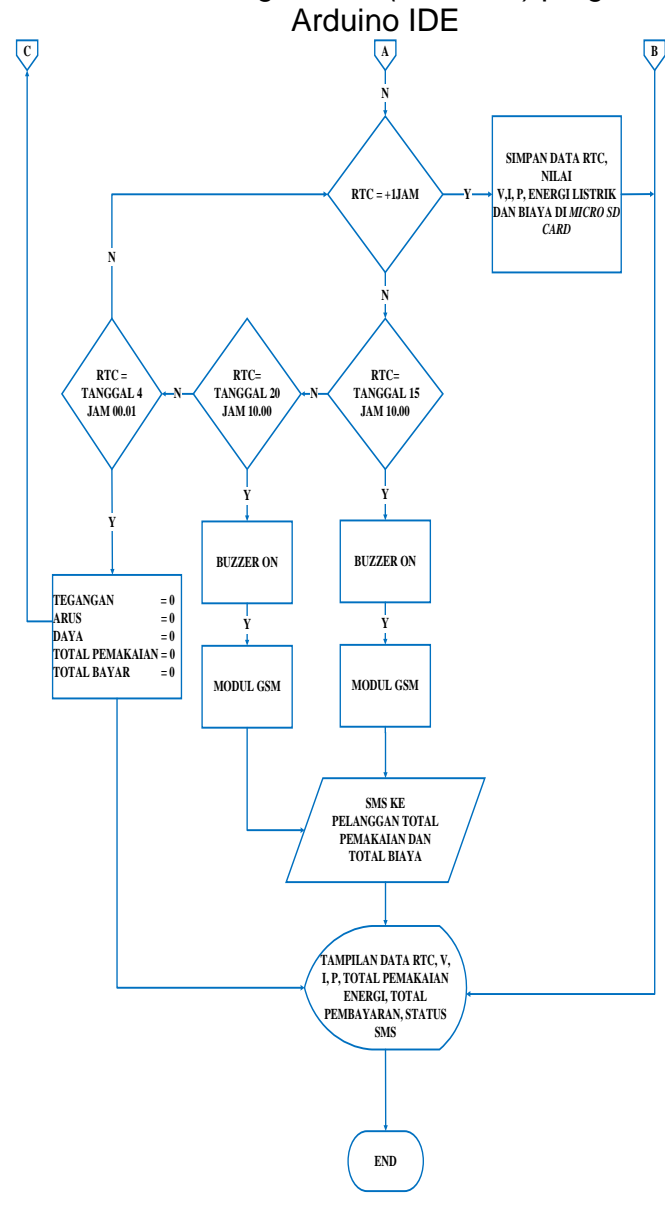

Gambar 11b. Lanjutan Diagram alir (flowchart) program Arduino IDE 
$\begin{array}{lcrr}\text { Perancangan } & \text { perangkat } & \text { lunak } \\ \text { (software) } & \text { pada } & \begin{array}{r}\text { pembuatan } \\ \text { sistem }\end{array} \\ \text { monitoring } & \text { energi } & \text { listrik } & \text { berbasis }\end{array}$ mikrokontroler ATmega328 dilengkapi dengan SMS menggunakan mikrokontroler ATmega328. Pada penelitian ini menggunakan RTC, Module GSM, Module Micro Sd Card, LCD, buzzer, sensor SCT013030, sensor tegangan. Output dari sensor arus dan sensor tegangan akan diteruskan ke mikrokontroler ATmega328 untuk dikonversi menjadi jumlah pembayaran pelanggan PLN. Informasi jumlah pemakaian, biaya, waktu dan tanggal ditampilkan ssecara real time pada LCD 20x4. Pelanggan dan petugas PLN dapat mengirimkan SMS sesuai dengan keyword SMS yang telah ditentukan, kemudian module GSM akan memverifikasi keyword tersebut, apabila keyword sesuai maka module GSM akan membalas SMS pelanggan atau petugas PLN. Setiap tanggal 15 dan 20 jam 10.00 disetiap bulannya, buzzer menyala, Module GSM akan mengirimkan SMS peringatan mengenai informasi jumlah pemakaian serta total pembayaran ke pelanggan PLN. Sistem berjalan selama 24 jam, pada tanggal 4 jam 00:01 untuk setiap bulannya sistem secara otomatis akan mereset data untuk mengulang siklus pembacaan jumlah konsumsi listrik pelanggan PLN. Seluruh data yang didapatkan akan ditampilkan di LCD.

\section{HASIL DAN PEMBAHASAN}

Realisasi monitoring energi listrik menggunakan SMS berbasis mikrokontroler ATmega328, ditunjukkan pada Gambar 12.

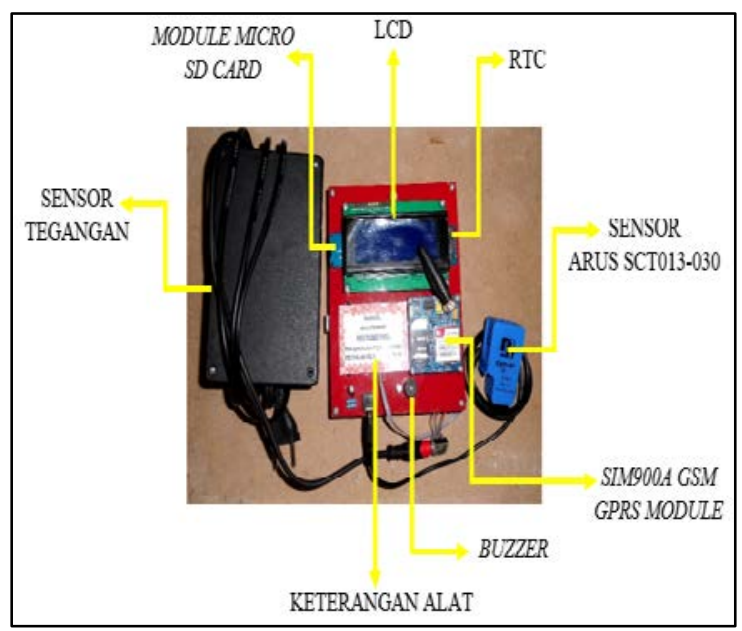

Gambar 12. Realisasi Alat
Menggunakan SMS Berbasis Mikrokontroler Atmega328 Menggunakan kWh Meter Pascabayar.

Hasil pengujian keseluruhan dari sistem bertujuan untuk mengetahui apakah sistem monitoring energi listrik menggunakan SMS berbasis mikrokontroler Atmega328 dapat bekerja dengan baik pada kWh meter pascabayar (konvensional I analog) sesuai dengan perencanaan. Berikut merupakan beberapa pengujian yang akan dilakukan terhadap sistem.

\subsubsection{Hasil pengujian dan pembahasan jumlah pemakaian energi listrik mengunakan pesan singkat oleh pelanggan PLN. \\ Pengujian dan pembahasan ini} dilakukan oleh pelanggan PLN, bertujuan untuk mengetahui apakah perintah untuk melakukan pengecekan pemakaian energi listrik yang akan dikirim menggunakan pesan singkat dapat diterima dengan baik sesuai perencanaan. Pengujian yang dilakukan dengan cara pelanggan mengirimkan SMS dengan kode "CEK" yang akan dikirim ke module GSM sesuai dengan nomor yang telah ditentukan. Penempatan rancang bangun sistem monitoring energi listrik menggunakan SMS berbasis mikrokontroler Atmega328 diletakkan pada kWh meter 1 fasa di Laboratorium Workshop \& Instalasi Listrik, Program Studi Teknik Elektro, Fakultas Teknik, Universitas Udayana, dengan current limit : 10A dan daya terpasang : $2200 \mathrm{VA}$. Alat ini dipasang dekat dengan $\mathrm{kWh}$ meter 1 fasa, kemudian sensor arus dikaitkan dengan fasa dari kWh dan sensor tegangan dihubungkan dengan kotak kontak dekat kWh meter yang terpasang. Penempatan rancang bangun sistem monitoring energi listrik menggunakan SMS berbasis mikrokontroler ATmega328 ditunjukkan pada Gambar 13.

4.1 Hasil pengujian Sistem Rancang
Bangun Monitoring Energi Listrik 


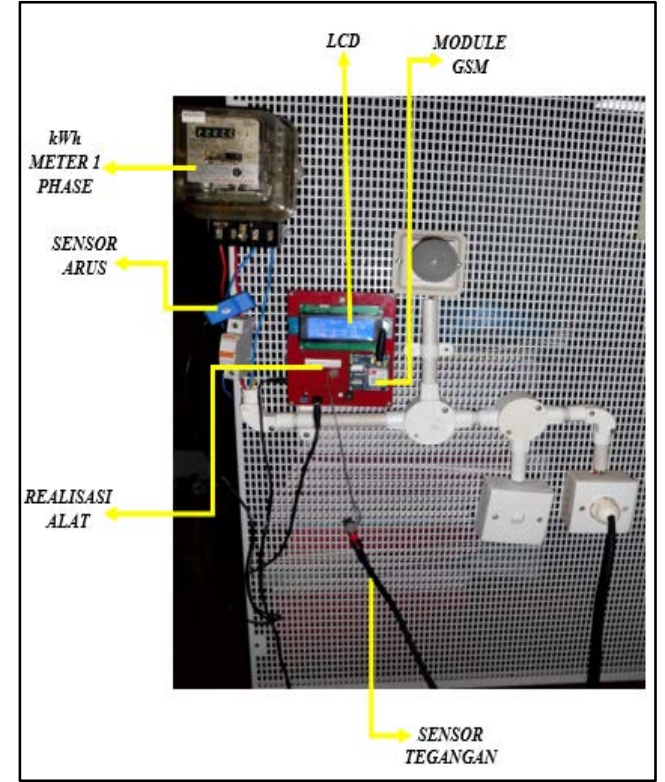

Gambar 13. Penempatan Alat

Pengujian dan respon dari module GSM dilakukan dengan mengirimkan perintah berupa pesan singkat kepada sistem, dimana pelanggan PLN telah mengirimkan SMS dengan kode "CEK", kemudian perintah ini akan diverifikasi oleh module GSM, dan diolah oleh mikrokontroler. Tampilan SMS pada saat pelanggan mengirim pesan dengan kode verifikasi "CEK" serta respon dari modul GSM untuk mengetahui informasi pemakaian energi listrik, ditunjukkan pada Gambar 14.

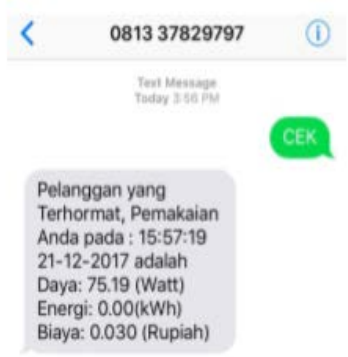

Gambar 14. Respon SMS Pelanggan PLN

SMS balasan berisikan informasi tanggal dan waktu, jumlah daya yang digunakan, jumlah pemakaian energi listrik (kWh) secara real time dan jumlah yang harus dibayarkan (Rupiah). Daya (Watt) didapatkan dari perhitungan berikut :

$$
\begin{aligned}
P \quad & =V \times I \\
& =229 \times 0,33 \\
& =75,57 \text { Watt }
\end{aligned}
$$

Energi (kWh) didapatkan dari perhitungan berikut:

$$
\begin{aligned}
\text { Energi } & =\frac{(V \times I)}{3.600 .000} \\
& =0,00002 \mathrm{kWh}
\end{aligned}
$$

Biaya (Rupiah) didapatkan dari perhitungan berikut:

$$
\begin{aligned}
& \text { Biaya } \\
& \begin{aligned}
&=((\mathrm{kWh}) \times \mathrm{Harga} / \mathrm{kWh}) \times 1,05 \\
&=(0,00002 \times 1.467) \times 1,05 \\
&= 0,0323 \text { Rupiah }
\end{aligned}
\end{aligned}
$$

Tampilan SMS yang diterima oleh pelanggan PLN sudah sesuai dengan perhitungan manual.

4.1.2 Hasil pengujian dan pembahasan jumlah pemakaian energi listrik mengunakan pesan singkat oleh petugas PLN.

Pengujian dan pembahasan ini dilakukan oleh petugas PLN, bertujuan untuk mengetahui apakah perintah untuk melakukan pengecekan pemakaian energi listrik yang akan dikirim menggunakan pesan singkat dapat diterima dengan baik sesuai perencanaan. Pengujian yang dilakukan dengan cara petugas mengirimkan SMS dengan kode "PLN" yang akan dikirim ke module GSM sesuai dengan nomor yang telah ditentukan.

Pengujian dan respon dari module GSM dilakukan dengan mengirimkan perintah berupa pesan singkat kepada sistem, dimana petugas PLN telah mengirimkan SMS dengan kode "PLN", kemudian perintah ini akan diverifikasi oleh module GSM, dan diolah oleh mikrokontroler. Tampilan SMS pada saat petugas mengirim pesan dengan kode verifikasi "PLN" serta respon dari modul GSM untuk mengetahui informasi pemakaian energi listrik, ditunjukkan pada Gambar 15. 


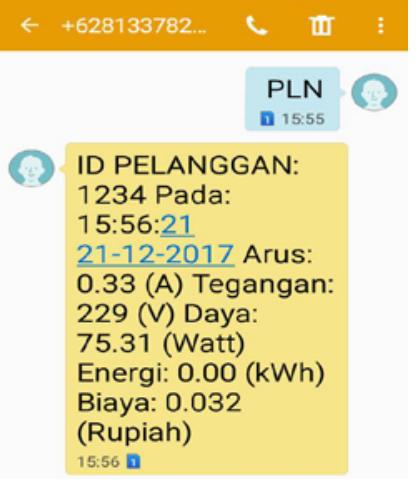

Gambar 15. Respon SMS Petugas PLN

SMS balasan berisikan informasi tanggal dan waktu, arus, tegangan, daya, jumlah pemakaian energi listrik (kWh) secara real time dan jumlah yang harus dibayarkan (Rupiah).

Daya (Watt) didapatkan dari perhitungan berikut :

$$
\begin{aligned}
P \quad & =V \times I \\
& =229 \times 0,33 \\
& =75,57 \text { Watt }
\end{aligned}
$$

Energi (kWh) didapatkan dari perhitungan berikut:

Energi $=\frac{(V \times I)}{3.600 .000}$

$$
=0,00002 \mathrm{kWh}
$$

Biaya (Rupiah) didapatkan perhitungan dari berikut:

$$
\begin{aligned}
& \text { Biaya } \\
& =\left((k W h) x^{H a r g a} / k W h\right) \times 1,05 \\
& =(0,00002 \times 1.467) \times 1,05 \\
& =0,0323 \text { Rupiah }
\end{aligned}
$$

Tampilan SMS yang diterima oleh petugas PLN sudah sesuai dengan perhitungan manual.

5. Hasil pengujian dan pembahasan data logger pemakaian energi listrik.

Pengujian data logger monitoring energi listrik bertujuan untuk mengetahui apakah data logger pada sistem berjalan sesuai dengan perencanaan. Pengambilan data dilakukan selama 24 jam yaitu dari tanggal 13 Desember 2017 pada jam 16.00 sampai dengan tanggal 14 Desember 2017 pada jam 15.00 .

Data yang disimpan dalam pengujian data logger monitoring energi listrik menggunakan SMS berbasis mikrokontroler ATmega328 merupakan data pengukuran beban pada kWh meter 1 fasa di Laboratorium Workshop \& Instalasi Listrik, Program Studi Teknik Elektro, Fakultas

\begin{tabular}{|c|c|c|c|c|c|c|}
\hline$\Delta$ & A & B & c & D & $\mathrm{E}$ & $\mathrm{F}$ \\
\hline 1 & Waktu & Tanggal & Arus (A) & Tegangar & Energi (kWh) & Biaya (Rupiah) \\
\hline 2 & 16:00:00 & $13-12-17$ & 0.04 & 226.58 & 0.00032 & 0.49 \\
\hline 3 & 17:00:00 & $13-12-17$ & 0.28 & 226.32 & 0.02003 & 30.86 \\
\hline 4 & 18:00:00 & $13-12-17$ & 0.83 & 223.79 & 0.15455 & 238.07 \\
\hline 5 & 19:00:00 & $13-12-17$ & 0.83 & 223.72 & 0.36526 & 562.63 \\
\hline 6 & 20:00:00 & $13-12-17$ & 0.84 & 224.56 & 0.57811 & 890.49 \\
\hline 7 & 21:00:00 & $13-12-17$ & 0.83 & 224.18 & 0.79233 & 1220.46 \\
\hline 8 & $22: 00: 00$ & $13-12-17$ & 0.84 & 222.04 & 1.00572 & 1549.17 \\
\hline 9 & 23:00:00 & 13-12-17 & 0.83 & 224.36 & 1.21742 & 1875.25 \\
\hline 10 & 0:00:00 & 14-12-17 & 0.84 & 226.39 & 1.43312 & 2207.5 \\
\hline 11 & 1:00:00 & 14-12-17 & 0.83 & 224.1 & 1.64594 & 2535.33 \\
\hline 12 & 2:00:00 & 14-12-17 & 0.84 & 224.85 & 1.85952 & 2864.3 \\
\hline 13 & $3: 00: 00$ & 14-12-17 & 0.83 & 224.66 & 2.07341 & 3193.77 \\
\hline 14 & 4:00:00 & 14-12-17 & 0.83 & 223.87 & 2.28583 & 3520.98 \\
\hline 15 & 5:00:00 & 14-12-17 & 0.84 & 224.59 & 2.49882 & 3849.05 \\
\hline 16 & $6: 00: 00$ & 14-12-17 & 0.84 & 224.65 & 2.71309 & 4179.11 \\
\hline 17 & 7:00:00 & 14-12-17 & 0.83 & 225.98 & 2.92637 & 4507.63 \\
\hline 18 & 8:00:00 & 14-12-17 & 0.84 & 226.65 & 3.14241 & 4840.41 \\
\hline 19 & 9:00:00 & 14-12-17 & 0.83 & 218.96 & 3.35343 & 5165.45 \\
\hline 20 & 10:00:00 & 14-12-17 & 0.83 & 218.04 & 3.56176 & 5486.35 \\
\hline 21 & $11: 00: 00$ & 14-12-17 & 0.82 & 218.85 & 3.76798 & 5804.01 \\
\hline 22 & $12: 00: 00$ & 14-12-17 & 0.84 & 221.16 & 3.97712 & 6126.16 \\
\hline 23 & $13: 00: 00$ & 14-12-17 & 0.83 & 222.13 & 4.18771 & 6450.53 \\
\hline 24 & $14: 00: 00$ & $14-12-17$ & 0.83 & 221.24 & 4.13862 & 6374.93 \\
\hline 25 & 15:00:00 & $14-12-17$ & 0.82 & 222.02 & 4.3956 & 6770.77 \\
\hline
\end{tabular}
Teknik, Universitas Udayana dengan menggunakan sebuah sensor arus SCT 013-030 dan sensor tegangan. File hasil data logger tersimpan oleh SD card berkapasitas $2 \mathrm{~GB}$ dengan ukuran file sebesar $3 \mathrm{~KB}$ selama 24 jam. File hasil data logger ditunjukkan pada Gambar 16.

Gambar 16. File Data Logger

\section{KESIMPULAN}

Kesimpulan yang dapat diambil berdasarkan hasil pengujian dan pembahasan yang dilakukan adalah sebagai berikut:

1. Alat ukur monitoring energi listrik menggunakan SMS berbasis mikrokontroler Atmega 328 telah dapat dibangun dan sistem pembacaan notifikasi penggunaan energi listrik sudah dapat dilakukan melalui SMS.

2. Peralatan terdiri dari rangkaian utama yaitu rangkaian mikrokontroler Atmega 328 sebagai pengolah data, module GSM sebagai pengirim dan penerima instruksi melalui SMS, module RTC sebagai penunjuk tanggal dan waktu secara real time, module micro SD card sebagai data logger, rangkaian sensor arus sebagai pembaca nilai arus dan rangkaian sensor tegangan sebagai 
pembaca nilai tegangan. Semua peralatan sudah bekerja sesuai dengan perencanaan.

3. Besar energi yang digunakan di kWh meter konvensional selama 24 jam adalah sebesar $4 \mathrm{kWh}$ dengan besar biaya yang harus dibayarkan pelanggan Rp. 6.374,93. Data logger yang dirancang menyimpan data arus, tegangan, energi terpakai dan biaya yang harus dibayarkan selama 24 jam, file hasil data logger tersimpan oleh SD card berkapasitas 2 GB dengan ukuran file sebesar $3 \mathrm{~KB}$.

\section{DAFTAR PUSTAKA}

[1] https://www.pertamina.com/industrialfuel/id/our-customers/pt-pln-persero/. Diakses tanggal 3 Januari 2018.

[2] Saadat, Hadi. Power System Analysis Third Edition. United State America : Victor Graphic. Inc. 2010.

[3] Saftari, Firmansyah. Proyek Robotik Keren dengan Arduino. Jakarta: PT. Elex Media Komputindo. 2015.

[4] Jufri, Hilman. Rancang Bangun Alat Ukur Daya Arus Bolak-balik Berbasis Mikrokontroler ATmega. Repository Universitas Sumatera Utara. 2013.

[5] http://sonoku.com. Diakses tanggal 18 Januari 2018.

[6] War Collage, Army. Power Buzzer Amplifer. 2006. 